$\underline{\text { Témoignage and Responsibility in Photo/Graphic Narratives of Médecins Sans Frontières }}$

By: Alexandra Schultheis Moore

Moore, Alexandra Schultheis. "Témoignage and Responsibility in Photo/Graphic Narratives of Médecins Sans Frontières.” Journal of Human Rights 12.1 (March 2013): 87-102.

This is an Accepted Manuscript of an article published by Taylor \& Francis Group in Journal of Human Rights on Mar 04 2013, available online at: http://www.tandfonline.com/10.1080/14754835.2013.754295.

***@ Taylor \& Francis. Reprinted with permission. No further reproduction is authorized without written permission from Taylor \& Francis. This version of the document is not the version of record. Figures and/or pictures may be missing from this format of the document. $* * *$

\begin{abstract}
:
This article analyzes photographic and graphic narratives of missions conducted by MSF in the Sahel (1984-1985), Afghanistan (1986), and Democratic Republic of the Congo (2005) for the ways in which the narratives construe the responsibility of their readers toward what they see as well as of MSF's missions toward those they serve, particularly in relation to MSF's official policy of témoignage or witnessing as advocacy. I read the chronotopes (space-time) within these books for how they represent suffering and position the reader as voyeur, philanthropist, or protester (Chouliaraki 2006). In their distinctive forms, these texts bridge the presence of immediate crisis and the larger historical framework through which it may be understood. As simultaneously visual and literary media, photo/graphic narratives work through the dual compulsions to show and to tell, both of which manifest through their formal manipulations of the structure of a humanitarian crisis. In their framing devices, these books play with constructions of temporality and distance (moral, intersubjective, and geographical) that govern "the ethics of mediation[,] the humanization of vulnerable others" (Chouliaraki 2011: 363) upon which humanitarian responsibility depends.
\end{abstract}

Keywords: Témoignage | Advocacy | Médecins Sans Frontières | Doctors without Borders | Photography | Graphic narratives | Humanitarianism

\title{
Article:
}

In one of his exemplary analyses of the humanitarian nongovernmental organization (NGO), Médecins Sans Frontières/Doctors without Borders (hereafter, MSF), anthropologist Peter Redfield returns to the etymology of "crisis" in order to challenge the assumption that it necessarily privileges immediacy over long-term conditions, or bare life over dignity and justice: "The English word crisis descends from the Greek root for discrimination or decision, designating a turning point, a moment of decisive change, or a condition of instability (OED)" 
(Redfield 2005: 335, emphasis in original). Redfield notes that what Hippocrates described as a turning point in disease "was adopted by Thucydides as a model for historical explanation, whereby facts could be organized into patterns of development. In such a narration of time, 'crisis situations became moments of truth where the significance of men and events was brought to light' ” (Starn 1971: 4, in Redfield 2005: 335). Redfield excavates these two temporalities (immediate "moment” and more lasting “condition”) and contexts (medical and historical) of "crisis" because they shape the humanitarian scope and ethos of MSF's missions as well as their ambiguities. The humanitarian responsibility invoked by MSF to assist those in catastrophic need reflects that rich, sometimes contradictory understanding of crisis itself.

In an effort to think through the stakes of responsibility in MSF's work, I follow the lead of recent critics in literary studies and human rights in examining "how story-telling is central to humanitarian action and how narratives of suffering are vulnerable to appropriation and misrepresentation by political institutions” (Wilson and Brown 2009: 25). If the stories we tell have the potential to connect us powerfully with imagined worlds, how might they also shape our imaginings of our responsibilities in and to the world we share? How do they mediate the space that connects imagination with social action? As many have shown, the expectations and effects of narratives of suffering - for example, the human rights report, humanitarian appeal, memoir, or novel—are linked closely to narrative form. Here I focus in particular on photographic and graphic narratives of missions conducted over the past 25 years by MSF, one of the best known and largest medical humanitarian aid organizations in the world, for the ways in which the narratives construe the responsibility of their readers toward what they see as well as of MSF's missions toward those they serve. The three books I will examine, which employ various combinations of photography, cartoon-style drawing, and narrative, result from partnerships between photographers and MSF to document the organization's efforts in the Sahel (19841985), Afghanistan (1986), and Democratic Republic of the Congo (2005). All three engage explicitly with the problem of at once defining and enacting humanitarian responsibility in formal and ethical terms. Those dual aspects of humanitarianism depend in turn upon the spatial and temporal dimensions of its representation: the distance between spectator and sufferer and the immediate and historical dimensions of crisis. I read the chronotopes (space-time) within these books for how they represent suffering and position the reader as voyeur, philanthropist, or protester. $^{1}$

When news images of humanitarian crises and of people "about to die" (Zelizer) work by depicting the ostensible "self-evidence and objectivity of painful feeling, and [thus...] the nation's duty to eradicate it” (Berlant 2000: 35, emphasis in original), they depend upon structures of identification and a supposed universalization of emotion to generate the viewer's sense of responsibility. Too often, especially in transnational addresses, these familiar patterns replicate the global structural inequities that deeply underlie the social suffering they document. In this article, I examine texts one or two steps removed from journalistic reporting in order to heed Wendy Hesford's and Lilie Chouliaraki's calls for an examination of visual rhetoric that offers 
alternatives to identity-based structures and that may "generate new discursive formations and cultural contexts through which human rights becomes a site of possibility and contestation" (Hesford 2011: 24, 196). Whereas Hesford sees humanitarianism (as opposed to human rights discourses) tied to "the logic of cultural recognition and its limitations in addressing social injustices” (Hesford 2011: 195), I look for the potential of alternative modes of address in the forms these narratives take. Wendy Kozol argues that graphic narrative, as distinct from news media reports, can potentially foster "ethical spectatorship, that is, forms of representation that foreground the dialogic interactions between ethical looking and the role of spectacle in transnational visual witnessing of human rights crises” (Kozol 2011: 166). I take up the question of ethical spectatorship in these books with particular attention to how their formulations of responsibility correspond to more conventional humanitarian appeals and to MSF's explicit commitment to witnessing as advocacy.

Salgado's (2004) Sahel: The End of the Road (photography), Haviv et al.'s (2005) Forgotten War: Democratic Republic of the Congo (photography), and Guibert et al.'s (2009) The Photographer: Into War-Torn Afghanistan With Doctors Without Borders (photography and hand-drawn graphic narrative) grew out of MSF-sponsored photographic campaigns to document and publicize its work. While some of the individual images in the books were published in news media when they were taken, the books' range of visual and narrative styles offers multiple perspectives on how the space-time representation of crisis produces distinct narratives of humanitarian responsibility. As books, these texts have a staying power that complicates the sense of immediacy implicit in conventional human rights appeals, news reports, and emergency medical relief efforts on the ground yet offer a potential bridge between the presence of immediate crisis and the larger historical framework through which it may be understood. As simultaneously visual and literary media, whose narrative arcs emerge through the relationship among discretely framed moments, photo/graphic narratives work through the dual compulsions to show and to tell (and the slippages between them), both of which manifest through their formal manipulations of the structure of a humanitarian crisis. More specifically, in their framing devices these books play with constructions of temporality and distance (moral, intersubjective, and geographical) that govern "the ethics of mediation[,] the humanization of vulnerable others" (Chouliaraki 2011: 363) upon which humanitarian responsibility depends.

\section{Témoignage and Responsibility}

A distinguishing feature of MSF, born in 1971 of its founders' (both doctors and journalists) medical aid work on behalf of those caught in the Nigerian civil war and a major flood in what is now Bangladesh, is its dual commitment to provide medical care "to people whose survival is threatened by violence, neglect, or catastrophe, primarily due to armed conflict, epidemics, malnutrition, exclusion from healthcare, or natural disasters" (MSF "Mission Statement”) and to perform témoignage: a blend of witnessing and advocacy on behalf of egregious human suffering in the areas where MSF staff are working. That combination of objectives raises the implicit question about the relationship between the kinds of responsibility 
engendered by its different roles. Although MSF explicitly defines itself as a civil, as opposed to a political, organization, it must nevertheless negotiate the political contexts framing its missions, particularly in "push[ing] the political to assume its inescapable responsibility" (Orbinski 1999: para. 7). MSF frames its own responsibility in the face of suffering as medical and moral — scientific and logistical on the one hand and overtly rhetorical on the other-with both animated by the deep structure of crisis to which responsibility responds. Delineated according to both a "'minimalist' biopolitics" ("the temporary administration of survival within wider circumstances that do not favor it”) and "the deeper humanitarian goal of reestablishing human dignity" (Redfield 2005: 344, 345), crisis determines the targeted scope of medical relief, the moral claim of the witness, and whether that claim is directed toward political actors, aggressors, potential donors, or some broader citizenry.

Redfield reminds us that a minimalist biopolitics does not lead to human dignity "other than [through] publicly demonstrating an attachment to that ideal at the moment of its abnegation," an insight that also reflects a danger inherent in identity-based strategies of humanitarian appeals. MSFs material and rhetorical spheres of action overlap to offer the protection of both bare life and human dignity as essential aims of humanitarian responsibility, making the question of how dignity is defined all the more urgent. ${ }^{2}$ In his Nobel Peace Prize acceptance speech on behalf of MSF in 1999, then president Dr. James Orbinski defines humanitarianism in universalizing terms of moral concern based on presumably shared and self-evident values of crisis, normalcy, dignity, rights, suffering, and action: "Humanitarian action ... aims to build spaces of normalcy in the midst of what is abnormal. More than offering material assistance, we aim to enable individuals to regain their rights and dignity as human beings” (Orbinski 1999: 131). This rhetoric posits a common humanity predicated on shared values that transcend structural imbalances and cultural difference. At the same time, the story of what constitutes a crisis, against that universalized state of normalcy, depends upon the different roles MSF might assume. For a doctor,

[a] patient improves, expires, or enters a chronic state. But for a historian, every age has its turning points and critical decisions amid turmoil. This sense of crisis stems less from the particularities of suffering per se, than the repeated discovery of moments of truth within them and the ordering of that truth into a revelatory narrative. Thus, the problem before us is not crisis per se but the very codification of crisis into a state, a condition of action, and the subsequent limiting of emergency to within these borders. (Redfield 2005: 347)

Orbinski turns to the discourse of rights and dignity to bridge temporal and spatial disjunctions between immediate crisis and history and emergency and normalcy, and this discourse finds its rhetorical expression in témoignage.

According to one MSF-UK newsletter, témoignage is "simply the act of being willing to speak out about what we see happening in front of us. In MSF, this means willingness to speak on behalf of the people we assist: to bring abuses and intolerable situations to the public eye” (MSF 
“Advocacy and Témoignage”). This awkward formulation, "the act of being willing,” captures some of the ambiguity inherent in its praxis: Is it a moral position, an inherent capacity (by virtue of being a member of the organization), or a political action? Does it presume that those suffering are unable or unwilling to represent themselves? As stated on the current, parent website, "MSF may speak out publicly in an effort to bring a forgotten crisis to public attention, to alert the public to abuses occurring beyond the headlines, to criticize the inadequacies of the aid system, or to challenge the diversion of humanitarian aid for political interests" (MSF “About MSF”). This statement is followed by a list of high-profile denouncements of state and corporate behavior from 1985 to the present. Implicit within the practice of témoignage, then, is both the capacity and opportunity ("MSF may speak out") of MSF staff to publicize injustice from multiple subject positions as well as the belief that listeners—potential donors, sympathetic or shamed political actors, other professional organizations in the field—ought to heed and respond to their efforts. In effect, MSF defines one facet of its responsibility as reminding others of theirs.

Redfield analyzes MSF's evolving ethos of témoignage, concluding that the praxis "has only grown more central to its activities and internal debates" (Redfield 2006: 8). In a statement from its 1995 meeting, MSF defined témoignage as comprising

the presence of volunteers among populations in danger, motivated by concern for the fate of fellow human beings and a willingness to be at their side and listen to them, as well as to carry out medical work among them; and the duty to report on the situation and the fate of these people. Where MSF is present as a witness to massive and repeated violations of human rights and/or humanitarian law (such as forced population displacements, refoulement [forced return], genocide, crimes against humanity and war crimes), then MSF may ultimately be forced to make public denunciations. (as quoted in Redfield 2006: 8)

In this fuller articulation of témoignage, "presence" combines with "motivation" to produce a "duty" to speak out, such that it becomes a responsibility rather than merely a capacity to be a witness.

The tension between offering medical relief as dictated by a minimalist biopolitics and speaking out about the structural and political contexts of emergency require a continual balancing act. The focus on both medical relief andtémoignage defines a scope of practice for logistical decision making in its missions; at the same time, it may either foreclose political engagement at the very moment of its great necessity or, more optimistically, offer an alternative temporality to the long-term work of juridical, political, and economic change to the structural conditions of the crisis at hand. MSF's expanding scope of practice from relatively short-term projects to the development of longer term missions (e.g., the treatment of endemic diseases such as malaria or HIV/AIDS, or the establishment of programs in chronically underserved countries such as Haiti, where MSF has worked since 1991) also impacts the temporal and spatial dimensions of témoignage. This shift calls for renewed attention to crisis and témoignage to attend more 
strenuously to their Thucydidean dimensions. When crisis becomes condition and exceptionality generates other forms of normalcy, no matter how unconscionable, certain humanitarian appeals — such as those built around crisis as shock and sudden rupture-lose their efficacy in galvanizing the spectator, demanding other narrative forms in their stead.

The relationship of témoignage to the spatial dimensions of responsibility works through a parallel paradox: much like the universalizing rhetoric of dignity it echoes as well as MSFs pledge to work "without borders," témoignage is geopolitically engaged in that it "confronts the basic territorial logic of the nation-state; in doing so, it also recalls the legacy of imperial expansion” (Redfield 2005: 336). At the same time, témoignage implicitly contracts the distance between safety and suffering by calling upon the relationship between them as a requirement to act.

\section{The Structure of an Appeal}

Whereas témoignage may be directed to a targeted audience, as in a letter-writing campaign or human rights report, humanitarian appeals typically address themselves as broadly as possible to the public to shape public opinion and/or to generate donations. Although the range of critical analysis of mediatized humanitarian appeals exceeds the space available even to summarize it here, two forms of appeal have particular bearing on the techniques employed by the photo/graphic narratives of MSF. One form works through documentary-style photography and personal, representative stories of victims. These techniques certify the crisis as real and immediate, while simultaneously establishing a distance between the potentially beneficent, ostensibly safe spectator and the obviously vulnerable subject that defines a unilateral humanitarian gesture at once possible and necessary. The humanitarian impulse in such efforts is quickened by the political legacy of "the articulation of justice with pity," a formulation Chouliaraki describes as circulating through discourses of "grand emotion" toward those who suffer (Chouliaraki 2010: 109). Such appeals work primarily through structures of (mis)identification and aim to move the spectator from the position of voyeur to philanthropist.

Chouliaraki identifies a second, “post-humanitarian” form of appeal that focuses on the viewer rather than sufferer of atrocity, the addressee of the appeal rather than its subject. "Drawing upon playful textualities," as opposed to realism, and embracing irony over pity, "this communicative structure challenges claims to 'common humanity', characteristic of earlier humanitarian genres, and replaces solidarity as action on human suffering with artful stories that promise to make us better people” (Chouliaraki 2011: 364). The “morality of irony" transforms potential "solidarity into self-centred consumerism, [and] ultimately reproduces rather than challenges the existing relations of power between the West and vulnerable others” (Chouliaraki 2011: 364). Those suffering are bracketed as viewers' identification with the humanitarian agent generates the force of the appeal. The two styles, based on photorealism and pity on the one hand and ironic, postmodern textual play on the other, "fail to sustain a legitimate appeal to action on vulnerable others,” Chouliaraki argues, because neither interrogates the structural imbalances that divide 
secure and vulnerable worlds nor "construe[s] the world as 'common and shared' to all" (Chouliaraki 2011: 373). In neither case do the appeals move the spectator further along the spectrum from voyeur to philanthropist to protester, who might seek both relief and justice.

The question remains whether the photo/graphic narratives of MSF which adopt these same formal representational strategies (documentary photography, hand-drawn cartoon images, or both) can affect that final move, one which implies a higher degree of responsibility for the spectator's secondary witnessing of the images of suffering. Can they formulate responsibility apart from the viewer's disidentification with those suffering and/or identification with MSF staff members, especially as partial byproducts of the organization itself? This challenge, combined with the increasing scope of MSF missions, underscores the need defined by trauma theorist E. Ann Kaplan for active witnessing as that which involves understanding the "structure of an injustice" as well as the avoidance of "empty empathy" (Kaplan 2005: 23, 93, emphasis added) generated by sentimental attachment to decontextualized images of suffering.

How, then, do the photo/graphic narratives of MSF-particularly their efforts at once to show and to tell of suffering - function rhetorically, aesthetically, and ethically as a form of active witnessing and témoignage which might galvanize the viewer/reader's responsibility to suffering into some form of action? In Chouliaraki's terms, how might these photo/graphic narratives transform the recognition of shared responsibility to ameliorate suffering into a potential for solidarity through "'proper distance': the recognition that it is this very asymmetry of power that must become the principle of solidarity upon which we act toward vulnerable others" and that vulnerability itself is a political rather than universal "question of injustice" (Chouliaraki 2011: 364, 377)?

\section{Témoignage and Photo/Graphic Narrative}

Photography plays a key and familiar role in both maintaining and disrupting these narratives of crisis and intervention, of vulnerable versus secure worlds. Many have commented on the politics of the objectifying, colonizing gaze inherent in photographic campaigns featuring shocking images, victims "deserving” of aid, and portrayals of abject helplessness. On the other hand, social documentary photography and other visual media can lead to deeper considerations of the contexts of human suffering, moving beyond narratives of the immediacy of crisis to offer a wider and deeper perspective on the systemic conditions that underlie violence and that often implicate spectators in its punitive effects.

Sebastião Salgado is perhaps one of the most recognizable photographers documenting humanitarian and environmental degradation around the globe, and the photographic project, Sahel: Man in Distress, later also published as Sahel: The End of the Road, is one of his earliest works. The product of a 15-month project in 1984-1985 to photograph the effects of drought in parts of Chad, Ethiopia (including Tigray province), Mali, and Sudan, the photographs were collected and published in different editions in France (1986) and Spain 
(1988) with proceeds going to MSF/Doctors without Borders; a few photos appeared in contemporary news stories. As Fred Ritchin writes in an introductory essay to the US edition of the book, only published in 2004, US coverage of the drought and famine at the time favored short-term engagements couched in the rhetoric of solidarity, charity, and pity: Hands Across America, We are the World, a People magazine story, a portfolio of Salgado's photos in the New York Times. The photographs gained more exposure in the United States in 1990 when they were included in a traveling retrospective (and exhibition book) of Salgado's work, An Uncertain Grace. As Ritchin notes:

[S]ince Salgado's work on the Sahel was rarely published in the U.S. press at the time, the photographs' engagement with the visceral reality of the famine and its aftermath was to some extent subverted, put off for another day. His images had to be labeled "art" in order to be widely exhibited in the United States; their artistry rather than their urgency then became the focus of the critique. The recorded fact of people dying (what Susan Sontag called the "footprint" of the photograph) and the concomitant issue of social responsibility - the stuff of the documentarywere short-circuited and made nearly irrelevant. (Ritchin 2004: 4)

Ritchin's critique underscores the importance of context in determining the legibility of the photographs. Those contexts may be multiple and conflicting: In keeping with the complex relationship between photojournalism and humanitarian NGO work, for example, Doctors without Borders announced the opening of its first office in the United States in conjunction with the New York exhibition of An Uncertain Grace. How, then, might we read the large format, beautifully printed volume, Sahel: The End of the Road, published two decades after the event it documents, depicting suffering so grievous that it's nearly impossible to imagine that many of its sufferers have survived? In what temporal framework do the photos exist today? What kind of responsibility do they call forth on behalf of those distanced by time, space, and perhaps life itself?

In her analysis of television news reports of distant suffering, Chouliaraki offers a schema for analyzing the combined effects of visual and verbal reporting along a spectrum of possible outcomes for the spectator: the fascination and minimum pity of the voyeur to the charity of the philanthropist to the sense of indignation, outrage, injustice, or complicity that galvanizes the protester. Chouliaraki evaluates spatial representations according to how closely the subject and her background are related, the level of uniqueness and differentiation of environments, and the relationship depicted between safe and dangerous spaces. Temporal dimensions receive parallel attention according to when the event is taking place, whether its past, present, or future seems most important, and whether the future, if it is invoked at all, looms far or near (Chouliaraki 2006: 86). These criteria-with the important addition here of how MSF staff members are represented in relation to those they serve as well as the environment-provide a framework for analyzing how both suffering and the responsibility for its amelioration are construed. Or, to build on Judith Butler's analysis of how grievable life is framed 
photographically (Butler 2010: 83), if the photograph extends the event, what is the field in which responsibility is newly constituted through Salgado's book?

The separation of visual and verbal elements of Sahel: The End of the Road (the captions are published in the back of the book, rendering it more legible as an art book whose images ostensibly stand apart from their contexts) makes specific locations difficult to pinpoint; however, even without the captions the photographs depict a varied geography with direct bearing on human suffering. Through Salgado's lens, the different regions of the Sahel appear variously, from an otherworldly depiction of a seemingly barren landscape, which spectral humans traverse with unknown purpose, to an apocalyptic take on the end of human civilization (the vulture hovering above the famine camp; silent, naked, waiting children; or a littered, depopulated landscape). Other depictions offer a larger social context, however precarious, through long and close shots of outdoor spaces (an encampment; a pathway lined with water jugs) and indoor spaces devoted to the minimal necessities of medical care, food, and shelter. Those indoor spaces appear only slightly less catastrophic than the outdoor ones, in that the necessities of bare life emerge in the carefully focalized mat, shawl, or bowl; yet these images are marked primarily by the failure of those few objects to sustain life and the inability to distinguish among some subjects the living from the dead. Salgado's movement across categories of "presumed, possible, or certain death," and the difficulty of distinguishing among them, destabilize conventional ways of reading and demand considerable "interpretative work by the public to complete what is not shown” (Zelizer 2010: 68).

Depictions of MSF and other NGO staff (and their limited equipment) offer similarly disturbing and unsettling conclusions. Pictured in iconic arrangements - in the operating room, hovering tenderly over a dying child - they are illuminated in relation to their patients, yet seemingly unable to save their lives. The spectator has as little access to their interiority as to those suffering the famine, and all the images portray a deep silence. As spectators in the Global North may more readily identify with the beneficent aid workers in the photos than those wavering at the edge of life or who have already passed over it, those aid workers function pedagogically to model a charitable response. At the same time, and to work against radically othering processes, Salgado consistently renders the individuality and social bonds of the sufferers through gesture and proximity - the communal prayer, the sharing of water, a parent's hand on a child. The perspectives he offers on his subjects "begin at compassion and lead from there to further recognitions. One of the first is that starvation does not obliterate human dignity. [...] Salgado did not photograph passive victims, and pity does not suffice” (Strauss 1991: 99). By paying close attention to these moments, viewers might recognize the compassionate gestures among sufferers as catalysts for engagement at least as powerful as those by the MSF staff.

In consistently making this argument through his photographs, states David Levi Strauss, Salgado redefines the responsibility of his field: "Eschewing the vaunted 'objectivity' of photojournalism, Salgado works in the realm of collective subjectivities, aspiring to that 
'transcendence of the Self that makes possible the epiphany of the Other' "' (Levinas 1972, as quoted in Strauss 1991: 99). The language of transcendence and epiphany borrowed from Levinas also references the spiritual or sacred dimension of Salgado's aesthetic, one which, depending on one's point of view, removes suffering from the realm of the political or provides another powerful vocabulary through which to articulate the terms of recognition of and responsibility to (rather than paternalistically for) those subjects. At its best in Levinasian terms, this aesthetic fosters the recognition of one's responsibility to another that precedes identity and, thus, exceeds the terms of the encounter at hand and any singular gesture of beneficence. In Hesford's summary of this ethical relation, “the face-to-face encounter," which invokes humanity as a witness, "breaks the objectifying gaze and moves beyond narcissistic recognition" (Hesford 2011: 50), asking the viewer to look beyond him or herself toward a larger ethical frame. As Mev Puleo writes, “At a time when our secular culture seems to lack a language to discuss morality, it is not surprising that the critics retrieve religious language to describe and discuss images that so deeply stir the conscious” (Puleo 1994: 4).

I want to insist with Hesford on this ethical relation and the visual field in which it operates as socially mediated and historically contingent, rather than otherworldly or wholly abstract (Hesford 2011: 52). In their temporal dimensions, Salgado's preference for black-and-white photography contributes to the sacred aura of timelessness as the images seem to take place in an undetermined past or present, seemingly escapable only through death. The “'decisive moment"“ of the photograph also exists, however, within a longer temporality that calls forth worldly responsibility (Ritchin 2004: 6). Salgado's 14 to 15 months in the Sahel to shoot this project provide one example. More telling is the collection's implicit narrative of political failure and the insufficiency of humanitarian aid alone to compensate for it. Images of desperate migrations or a lone helicopter hovering in the background behind those suffering the famine aim to "sprovoke a discussion' [... of] the issues behind the photographs” (emphasis added). ${ }^{3}$

Salgado's often iconic depictions of victims and aid workers and exquisite care with framing, focus, and formal arrangement give the images a hyperdramatic quality that has been critiqued for romanticizing and aestheticizing suffering. This danger, when "the image tends to bring forth the formal properties of suffering [...] and take attention away from the content of suffering as a painful reality for somebody out there in the world" (Chouliaraki 2006: 50), decreases if we examine the narratives implicit in the arrangement of the photographs and even more so if verbal and visual texts are reunited. Taking the first third of the book as an example, the photographs move from stark images of sufferers against an unrelentingly desolate backdrop to the continuity of social bonds (men praying, children playing, a hand comforting the dying) in bare life in the camps to, finally, the importance of those bonds and their cultural expressions in death, visible in the three women reading next to two shrouded corpses in an unmarked landscape.

The captions offer a richer context for the photos not only in their descriptive content-the form of narration that merely confirms the fact of suffering and aligns closely with the perceptual realism of the image itself_-but also in, what Chouliaraki terms, their narrative and expository 
functions, including elements of storytelling (galvanizing emotion toward the suffering depicted) and argument or opinion in the pursuit of justice (Chouliaraki 2006: 77-78). In the expository mode, for instance, the caption for the first photograph in the book, of two distant figures walking out of the frame across a desert landscape bare except for a distant mountain and a gigantic bush in the center of the photo, reads: "On the outskirts of Tokar. Before the drought of 1973, this region was perhaps the most prosperous in the Sudan. It was the chief supplier of cotton, the source of wealth for this delta population. Now the warehouses are empty and the villages deserted. Sudan, 1985" (Salgado 2004: 125). The caption is noteworthy not only for its attention to history (thereby stretching the moment of the photograph) but also for its insistence on describing what the photograph does not show: a population, warehouses, a village. Another caption to a photograph of the shrouded corpses of a parent and child on the ground surrounded only by a few footprints, stones, and dead grass expresses outrage at the political failure that both initiated the journey and led to this conclusion: "Welo province, Ethiopia. They have walked, crossing mountains, enduring hunger and cold. They have hidden and waited, clinging to hope, and have pressed onward. But why flee? Why walk so far and suffer so greatly only to end up like this? Ethiopia, 1984" (Salgado 2004: 129). Here, too, the caption exceeds the precise limits of the photograph with its ambiguous temporality in verb tenses and distance between the speaker and the subjects, an ambiguity that allows the caption to describe others who have not (yet, perhaps) met the same end.

Chouliaraki combines the criteria for interpreting temporal and spatial representations into an overall chronotope of suffering that measures four attributes for determining a work's effectiveness in moving the spectator along the path from voyeur to protester:

concreteness- - "shows the concrete context of suffering as a physical space”;

multiplicity— “moves spectators through the multiple physical contexts of suffering"; specificity — "shows the context of suffering as a singular space ... or individualizes the sufferer”;

mobility- "which connects the contexts of safety and danger, suggesting a specific relationship of action between them.” (Chouliaraki 2006: 87)

Upon first view as a photographic book, Sahel: The End of the Road at once seduces the spectator through the beauty of its images and insists on a limited voyeuristic responsibility for that view by anchoring it in specific subjects, spaces, and cultural practices. Mobility in the sense defined above increases when captions and images stand together and when we put this content in the context of the front matter of the book with its critique of US publishers' earlier refusal of the material; however, mobility plays a scant role in proposing a course of action that attends to relief and repair, charity, and justice. As noted above, the images "provoke a discussion" rather than outline a response. Even the effort to cultivate philanthropy is limited by its only tenuous reminders of the project's link to MSF. While not proscriptive, Salgado's images consistently 
portray suffering as a form of injustice and as his photographs "leave remarkably durable afterimages that reappear long after one walks away from them” (Strauss 1991: 96), they might foster deliberation in anticipation of a shared future. His visual language of epiphany and transcendence speaks at once to the radical humanity of the vulnerable as well as to the enormity of the gap between recognizing that humanity and the political will to act upon it.

Ron Haviv, Gary Knight, Antonin Kratochvil, Joachim Ladefoged, and James Nachtwey's Forgotten War: Democratic Republic of the Congo also underscores the power and importance of photographs as a form of remembering with both present and future implications. The book is a product of one of several collaborative projects between MSF and the VII photo agency, formed by an initial seven photojournalists in September 2001 "to produce an unflinching record of injustice and the people caught up in the events they depict" (Haviv et al. 2005). The relationships MSF builds with VII and other photojournalists take different forms, from paid assignments to "provid[ing] access and logistical support-including local transportation, meals, lodging, and information - to photographers who are working on issues or in regions where MSF is also working” (Walker 2009: para. 6). Both parties recognize the complexity of this relationship, especially when photojournalists gain access to stories with only limited obligations to MSF for the resulting images. From a photojournalistic perspective, as David Walker writes, "For nearly 40 years, Doctors Without Borders ... has been a catalyst for world-class journalism from difficult places around the globe. And its role in bringing epidemics and humanitarian disaster to the world's attention is bound to expand as news organizations cut back their international coverage." Yet, that access for photojournalists is also circumscribed by MSF security guidelines and priorities, as MSF representative Jason Cone explains in the same article: “'They can't just jump out of the car and shoot' wherever and whatever they want, Cone says. 'We're an NGO. We're not about independent journalism. We're up front with [photographers] about that. They have to be willing to accept that they might be held back in terms of their reporting' " (Walker 2009). Forgotten War as a small format, limited-run volume of five photographers' views in 2004 of the Democratic Republic of Congo (DRC) is neither strictly news reportage nor art, although many of the images draw attention to their own formal characteristics. It functions most clearly among the three books under consideration here as a form of témoignage in MSF's own terms. With a "Foreword" by MSF Executive Director Nicolas de Torrenté, the volume aims to "make visible to the world" the cost of war, endemic disease, and sexual violence upon local populations in the DRC and to motivate the spectator's refusal of "a kind of normalization of the unacceptable" (Torrenté in Haviv et al. 2005) depicted in the images. The introduction also instructs viewers to see both individuals and the larger context of war and disease in the images that follow.

Forgotten War uses rhetoric of potential temporal and spatial proximity. That the war has been "forgotten," for instance, implies that it was once known; that the reader will see how conditions of extremity can become "normal," as opposed to exceptional, implies a comparison with his or her own understanding of normalcy. The movement from immediate crisis to persistent need also 
clears space for deliberation of the very kinds of normalcy MSF cites as at the heart of its objectives. The decision of what to shoot and what to publish in this context reflects the photographers' vision of what ought to be different; determinations that can only be made in the context of evaluating what might count as "normal" and the structural inequalities that undergird those attributions. Their five portfolios within the book focus, in order, on the following: on internally displaced persons in different regions and camps; Bunia, with particular attention to its hospital; HIV/AIDS patients at an MSF clinic in Bukavu; sex workers in Kinshasa; and individual suffering caused by malnutrition, disease, and war in various districts of the DRC. Their arrangement offers an exposition of how the radical social disruptions (rather than the wounds of weaponry) inflicted upon civilian populations in war lead to severe, chronic forms of suffering. The arrangement of portfolios also situates the overtly medical, institutional work of MSF in the hospital and clinic within the larger project of witnessing extreme social upheaval and endemic suffering. The structure and themes of the book parallel, in other words, MSF's dual responsibility for medical aid andtémoignage as well as the desire to call upon their audiences to assume responsibility themselves.

The individual portfolios have distinct aesthetic perspectives on their subjects which, taken together, offer high degrees of the concreteness, multiplicity, and specificity of suffering. Haviv's color photographs of internally displaced persons, for example, feature contrasting colors and striking lines that lead the eye to different corners of the images and create tension with whatever image of suffering lies at the center (an illuminated cross at a child's funeral, a woman framed by bed sheets in the hospital, a UN truck departing down a dusty road). These images contrast with the final black-and-white portfolio by Nachtwey, whose intimate perspective often focuses on the laying on of hands: a mother stretching her arms over her sick children, a wife comforting her husband, or MSF staff treating a patient. Significantly in these photos, Nachtwey shows only the hands of MSF workers, at once keeping the focus on the patients and inviting a philanthropic response.

Between these bookends, Kratochviv's portfolio of an MSF HIV/AIDS clinic features much more abstracted images, often with a body part of the foregrounded human subject (a bent back, an x-ray, a head) blurred against a focalized background. His images thus bespeak their own limits and draw attention to a situated perspective, as opposed to striving for any coherent, objective, totalizing, or unanchored view. Kratochviv's one direct, focused portrait of a female patient has a double-page spread in the book and, although her face fills the page with only the suggestion of a clinic room behind her, the caption references the MSF staff omitted from the photo: “An AIDS patient being cared for by MSF doctors at a local hospital in Bukavu.” This, too, reminds the spectator of the limits of what she can see. Knight's tilted and askance perspectives and Ladefoged's depictions of sex workers often juxtapose body parts of various subjects, refuting any suggestion of a wholistic or self-evident perspective.

In one image, Ladefoged's photograph of a patient on a gurney, lying beneath a poster of a pregnant woman's belly and being examined at the MSF sex worker clinic, underscores its own 
status as representation and plays with the question of visual address. Responsibility in the poster is defined by the pregnant woman's hands encircling her belly and the command, "Proteger a seu bebé/contra a aids/é mais do que un dever/É un direita” [Protect your baby against AIDS/It is more than a right, it's a duty]; however, in Ladefoged's photograph that message, and thus the scope and locus of responsibility, is also reflected in both the patient's and the doctor's hands, respectively exposing and examining the patient's abdomen. Rather than provide a clear portrait of injustice and responsibility, the photograph portrays complex and competing narratives. The poster with its white body, Portuguese text, paternalistic and imperative tone, and language of rights and duties offers an ironic reminder of the DRC's earliest European contacts and, perhaps, the centuries-long history of disastrous foreign involvement. The body (naked except for a partial sleeve) in the poster is marked primarily by race and pregnancy, whereas the living subjects of the photograph — the doctor and the patient — are defined by profession, highlighted with visual referents such as the doctor's white robe and patient's silver-painted toenails. The ostensible "natural" everyday of maternal responsibility of the poster, which is apparently not so natural that it can avoid a stern reminder, contrasts vividly with the social contexts of the subjects. Finally, none of these three positions - poster, patient, or physician-invites the viewer's identification, instead deflecting it with the backs of the doctor's robe and patient's jacket. The proximity the camera provides to this semi-intimate scene can only be justified, then, through a consideration of the terms - historical, political, medical—that make it possible.

Forgotten War: Democratic Republic of Congo ultimately serves as an injunction to remember and respond because the roots to the crisis are long, tangled, and transnational and its scope so pervasive; although, in terms of the mobility Chouliaraki outlines, it does not specify the terms through which viewers might feel interpellated. As opposed to the visual language of epiphany and transcendence of Salgado's work, these photographers underscore the impossibility of a full revelation of distant sufferers through off-kilter framing, the tension between focused and blurred subjects, and the insistence on partial perspectives. The depictions of ostensibly private moments, including the sense of intrusion the camera conveys when it reveals naked women in childbirth or family members mourning a dead child, provide concrete examples of just what the "normalization of the unacceptable” might include. Rather than a proximity of intimacy and immediacy, the images illuminate and demand recognition of that "asymmetry of power" between spectator and sufferer, that "proper distance" Chouliaraki argues is necessary for the pursuit of justice. The images do not circle back, so to speak, to remind the viewer to contribute to MSF's work so much as to frame the scope of the crisis in large and complex terms that exceed the capacity of any single organization to respond to it.

Avoiding the privileged association between the obviousness of suffering and its immediate response as well as cultivating the conditions for deliberation are precisely the claims that supporters of the innovative potential of graphic narrative make for it. According to Hillary Chute, graphic narrative's formal characteristics, its overt attention to the structures of representation, produce the possibility for ethical engagement: "Its formal grammar rejects 
transparency and renders textualization conspicuous, inscribing the context in its graphic presentation” (Chute 2008: 457). As its title suggests, The Photographer: Into War-Torn Afghanistan With Doctors Without Borders, approaches this task through a focus on Didier Lefèvre as both subject of his 1986 photographic assignment with MSF and witness to the medical team's work. These two roles are reflected in the multimodal narratives that compose the book: Lefèvre's black-and-white photographs, Emmanuel Guibert's graphic narrative (based on Lefèvre's stories of his trip and undertaken 13 years later), and Frédéric Lemercier's design and coloring of the final product. These different modes of storytelling blend into one another: The different forms are interwoven and interspersed to tell the story, graphic narrative textual frames overlay some photographs, and an earthy palette that, especially in a book of this length that requires a sustained reading, emphasizes the formal parallels between the graphic and photographic storylines. The interaction of these modes of representation moves the reader back and forth between what Lefèvre sees and how he reacts. The author-witness thus serves at once as a surrogate and model for the more removed spectator (the reader), compressing the distance between them as well as between the viewer and the subjects of Lefèvre's work, even as it offers, accordion-style, to expand that distance by displacing concern for the victims onto that of the witness.

The Photographer traces Lefèvre's journey from innocence and naïveté to experience as he accompanies a small MSF group in a caravan into northern Afghanistan to staff their small, remote clinics. Beginning and ending in Paris, the book is divided into three parts, documenting his introduction to Pakistan, Afghanistan, and MSF's work; the arduous trek across war zones, high passes, and rivers and the work at the clinics; and Lefèvre's decision to leave the group and return to Pakistan and then home on his own. Although the medical work is at the literal center of the book and is portrayed with genuine admiration, the narrative arc and dramatic tension depend on Lefèvre's direct, personal experiences, reaching their climax in his dangerous departure without the rest of the MSF team and his near death. The visual centerpiece of the book, a double-page spread of what he believes will be his last photo, follows an extended, gray and black graphic narrative sequence of his guide abandoning him on a high pass, Lefèvre losing his temper at his exhausted horse, beating the horse with his fists, and then lying down in the path to write his last diary entry and take his final photos: "I take out one of my cameras. I choose a $20 \mathrm{~mm}$ lens, a very wide angle, and shoot from the ground. To let people know where I died. (Click.)" (Guibert et al. 2009: 219). Switching to Lefèvre's direct perspective, three large format photographs (two split-page images followed by one full-page image) of his horse on the rough rock and snow path and against a stormy background lead to the panoramic view of the forbidding, uninhabited pass and valley below. The progression in image size and realism of the preceding images and poignant text that sets up this photograph enhance its emotional weight and invite the viewer's direct identification with it. This dramatic image - devoid of signs of war, MSF, or Afghan people-locates suffering solely within the photographer who has left MSF to test himself against the rigors of Afghanistan. 
The focus on Lefèvre functions as a (successful, if the measure is the wide circulation of The Photographer, especially compared with the other two books) narrative device that provides a compelling point of identification for distant readers curious about MSF or Afghanistan as well as an example of "inequality of lives" inherent in humanitarianism (Fassin 2010: 239). As Didier Fassin, former MSF board member writes, such inequalities result not from "theoretical premises or from individual prejudices. They are structural aporias of humanitarianism which are grounded in the asymmetry of the objective risk of death and of the subjective relation of compassion" (Fassin 2010: 255). The Photographer both re-instantiates those asymmetries and makes them available for scrutiny. On the one hand, Lefèvre's photographs, dark in tone, dense in terms of their visual content, and large in number, appear in small, sometimes tiny format that usually corresponds to the size of the much simpler graphic narrative frames yet makes the rich subject matter of individual photographs difficult to discern completely. On the other hand, the relationship between the two media provides multiple contexts through which to consider the position of Lefèvre in relation to the MSF team and those they treat. This interplay of graphic and photographic content "establish[es] what [Chute] [...] term[s] an expanded idiom of witness, a manner of testifying that sets a visual language in motion with and against the verbal in order to embody individual and collective experience, to put contingent selves and histories into form" (Chute 2010: 3, emphasis in original).

The "idiom of witness" of the graphic narrative has a pedagogic function as it reflects Lefèvre's admiration for the MSF team and distress at the individualized and specific suffering of the Afghan people he witnesses. At the same time, it situates the photographs in specific contextscultural, gendered, geographic, and political. The complex relationship between the MSF team"those who have a moral involvement in the humanitarian project, who are called 'volunteers' but receive a regular salary" - and himself as one of "those who are not related to the humanitarian saga, since they are simply 'employed' by the organization” emerges, for instance, in his decision to return on his own (Fassin 2010: 248). Over 16 frames, Lefèvre and team leader Juliette Fournot debate who has responsibility for his safety now that his specific task of documenting the work at the clinic has ended. Responsibility, as a product of asymmetry, becomes subject to trade as they negotiate their positions vis-à-vis one another: "So I'm handing back to you the responsibility that I have over you. You're a big boy. If you want to leave, leave,” Juliette finally tells him (Guibert et al. 2009: 155). The gendered language works on multiple levels to situate responsibility in a larger context: It reflects Juliette's frustration with his insistence on leaving the group and denotes the limits of her responsibility over her mission, it features as a significant milepost in Lefèvre's own quest as hero in his own story "to be left to my own devices and have to manage” (Guibert et al. 2009: 154), and it references an extensive portrayal earlier in the book of the cultural sensitivity of the MSF team and of Juliette in particular (of the responsibility to work responsibly in local contexts). "Her role, and her immersion in Afghan society where she spent her teenage years," as Chris Hedges notes, "repeatedly shatters easy stereotypes about Afghan and Muslim culture" (Hedges 2009: para. 4). Her language of acquiescing to his demand for independence also echoes the latent maternalism 
in humanitarian responsibility more broadly, invoking at once an ethics of care and the structural imbalance of parents and children.

The interplay of graphic narrative and photography provide a richer frame for the absence of any visual depiction of war as direct conflict in the book. If graphic narratives

as témoignage potentially "put pressure on dominant conceptions of trauma's unrepresentability" (Chute 2010: 182), without masking their own representational strategies, here the two narrative strands reveal the war through "damage done to bodies and souls by shells, bullets, and iron fragments, and the frantic struggle to mend the broken” (Hedges 2009). Although the graphic narrative emphasizes the telling of Lefèvre's personal story, it also invites a deeper reading of the photographs by characterizing the photographer's emotional reaction to the suffering he captures on film. The photographs, meanwhile, emphasize proximity to their subjects and the proximity of those subjects to danger: the ground-level view of Lefèvre's shot on the pass, close-ups of the basic surgery available for wounds caused by shrapnel and household accidents, the view MSF staff have from the porch of their rudimentary clinic. In terms of Chouliaraki's chronotope of suffering, then, The Photographer encompasses all four elements of concreteness, multiplicity, specificity, and mobility. The last of these, which, again, "connects the contexts of safety and danger, suggesting a specific relationship of action between them" (Chouliaraki 2006: 87), is achieved through the dialogue of forms and enhanced by the profiles of key figures at the end of the text. Because the book functions as a posthumous tribute to Lefèvre and his attachment to Afghanistan as well as to the dedication of humanitarian workers (and was published long after the Soviet invasion it documents), it reinforces MSF's broad mission of medical humanitarianism and témoignage, rather than a specific political goal, and enjoins the reader on the level of philanthropy.

\section{Conclusion}

MSF's practice of témoignage is central to the organization's mission and its larger contribution to the broad understanding of humanitarianism as a project that entails both medical relief and the pursuit of justice. As such, it operates officially in registers of technical-scientific discourse and moral universalism (which is also invoked to legitimize targeted denunciations). These discourses frame responsibility through the obviousness of suffering and injustice on the one hand and, in exhorting others to assume their responsibilities, on the dynamics of identification on the other.

As texts made possible by the sponsorship of MSF yet not beholden to it, the photo/graphic narratives construe responsibility in an expanded register of témoignage, which, at times, offers alternatives to models of responsibility that are based upon identification with humanitarians (proximity), disidentification with those suffering (distance), or an abstracted universalism. The books' serious play with the chronotopes through which they structure the relationship between spectator and the subject draw attention to representational self-reflexivity and the incongruences between perspectives and/or visual and verbal components. Notwithstanding their differences, all 
three books underscore the partiality of their own constructions, their historical embeddedness, and their aesthetic qualities, characteristics that ask for a reciprocal responsibility from readers. These books do not define concrete political goals or strategies; however, at best they may foster the consideration of what Chouliaraki terms, "agonistic solidarity”: “Agonistic solidarity is neither about the sharing of the same humanity for all nor the sharing of our own feelings for distant others but about the communication of human vulnerability as a political question of injustice that can become the object of our collective reflection, empathetic emotion and transformative action” (Chouliaraki 2011: 377).

\section{Notes}

1. I take these three positions, marking key points on a spectrum from passive to active engagement with representations of suffering and the conditions that underlie them, from Chouliaraki (2006: 145-146). Although Chouliaraki analyzes television news depictions of suffering, her focus on the chronotope of representation is particularly relevant to the kinds of texts I address here.

2. Dr. James Orbinski emphasizes, "MSF was born out of an understanding of the role humanitarians could play in shaping public opinion. It insisted on the responsibility not just to act but to speak out in solidarity against violations of human rights and international humanitarian law” (Orbinski 2006: 69).

3. Puleo quotes Salgado's frequent claim, "I'm not showing these pictures to make anyone feel guilty, but to provoke a discussion” (Puleo 1999: 10, fn 11).

\section{References}

1. BERLANT, Lauren. 2000. “The Subject of True Feeling: Pain, Privacy, and Politics”. In Transformations: Thinking Through Feminism, Edited by: Ahmed, Sara, Kilby, Jane, Lury, Celia, McNeil, Maureen and Skeggs, Beverly. New York, London: Routledge.

2. BUTLER, Judith. 2010. Frames of War: When Is Life Grievable?, New York: Verso.

3. CHOULIARAKI, Lilie. 2006. The Spectatorship of Suffering, London: Sage Publications.

4. CHOULIARAKI, Lilie. 2010. Post-Humanitarianism: Humanitarian Communication beyond a Politics of Pity.International Journal of Cultural Studies, 13(2): 107-126.

5. CHOULIARAKI, Lilie. 2011. "Improper Distance": Towards a Critical Account of Solidarity as Irony. International Journal of Cultural Studies, 14(4): 363-381.

6. CHUTE, Hillary. 2008. Comics as Literature?: Reading Graphic Narrative. Publications of the Modern Language Association of America, 123(2): 452-465. 
7. CHUTE, Hillary. 2010. Graphic Women: Life Narrative and Contemporary Comics, New York: Columbia University Press.

8. FASSIN, Didier. 2010. "Inequalities of Lives, Hierarchies of Humanity: Moral Commitments and Ethical Dilemmas of Humanitarianism”. In In the Name of Humanity: The Government of Threat and Care, Edited by: Feldman, Ilana and Ticktin, Miriam. Durham: Duke University Press.

9. GUIBERT, Emmanuel, LEFÉVRE, Didier, LEMERCIER, Frédéric and (Trans. Alexis Siegel). 2009. The Photographer: Into War-Torn Afghanistan with Doctors without Borders, New York, London: First Second.

10. HAVIV, Ron, KNIGHT, Gary, KRATOCHVIL, Antonin, LADEFOGED, Joachim and NACHTWEY, James. 2005. Forgotten War: Democratic Republic of the Congo, Millbrook, NY: de.Mo.

11. HEDGES, Chris. 2009. What War Looks Like: Review of The Photographer: Into War-Torn Afghanistan With Doctors Without Borders. The New York Times, May 20, [Online].

Available:http://www.nytimes.com/2009/05/24/books/review/Hedges-t.html [March 2012]

12. HESFORD, Wendy S. 2011. Spectacular Rhetorics: Human Rights Visions, Recognitions, Feminisms, Durham, London: Duke University Press.

13. KAPLAN, E. Ann. 2005. Trauma Culture: The Politics of Terror and Loss in Media and Literature, Rutgers, NJ: Rutgers University Press.

14. KOZOL, Wendy. 2011. “Complicities of Witnessing in Joe Sacco's Palestine”. In Theoretical Perspectives on Human Rights and Literature, Edited by: Goldberg, Elizabeth Swanson and Moore, Alexandra Schultheis. New York, London: Routledge.

15. LEVINAS, Emmanuel. 1972. L'Humanisme de l'autre homme, Montpelier: Fata Morgana.

16. ORBINSKI, James. 1999. Médecins Sans Frontières-Nobel Lecture Oslo, , Norway December 10, [Online]. Available:http://nobelprize.org/peace/laureates/1999/msflecture.html [March 2012]

17. ORBINSKI, James. 2006. An Imperfect Offering: Humanitarian Action for the Twenty-First Century, New York: Walker Publishing Company.

18. PULEO, Mev. 1999 [1995 Reprint]. The Prophetic Act of Bearing Witness: The Work of Sebastião Salgado. ARTS 7-12. 11, 2

19. REDFIELD, Peter. 2005. Doctors, Borders, and Life in Crisis. Cultural Anthropology, 20(3): 328-361. 
20. REDFIELD, Peter. 2006. A Less Modest Witness: Collective Advocacy and Motivated Truth in a Medical Humanitarian Movement. American Ethnologist, 33(1): 3-26.

21. RITCHIN, Fred. 2004. “Introduction: Twenty Years Ago, and Later”. In Sahel: The End of the Road, Edited by: Salgado, Sebastião. Berkeley: University of California Press.

22. SALGADO, Sebastião. 2004. Sahel: The End of the Road, Berkeley, CA: University of California Press.

23. STARN, Randolph. 1971. History and “Crisis.”. Part and Present, 52(August): 3-21.

24. STRAUSS, David Levi. 1991. Epiphany of the Other. Artforum International, 29: 96-99.

25. WALKER, David. 2009. How NGOs Work with Photographers: Doctors Without Borders. Photo District News, September 16, (PDN). [Online].

Available: http://www.pdnonline.com/pdn/index.shtml [March 2012]

26. WILSON, Richard Ashby and BROWN, Richard D. 2009. Humanitarianism and Suffering: The Mobilization of Empathy, Cambridge: Cambridge University Press.

27. ZELIZER, Barbie. 2010. About to Die: How News Images Move the Public, New York, Oxford: Oxford University Press. 